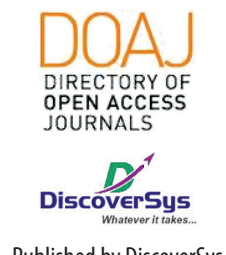

Published by DiscoverSys

\title{
Topical application of purple cabbage (Brassica oleracea L. var. capitata f. rubra) ethanol cream extract of dermic collagen on male Wistar rats (Rattus norvegicus) exposed to ultraviolet B
}

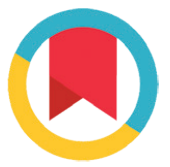

CrossMark

\author{
Komang Jegek Triangga Apsari, ${ }^{1}$ I Gusti Ayu Dewi Ratnayanti, ${ }^{2 *}$ \\ I Gusti Komang Nyoman Arijana, ${ }^{2}$ I Wayan Sugiritama ${ }^{2}$
}

\section{ABSTRACT}

Background: Purple cabbage or also known as red cabbage (Brassica oleracea $L$. var. capitata $f$. rubra) contains polyphenols, especially anthocyanin (cyanidin-3-diglucoside-5-glucoside). Anthocyanin has a protective effect against radical oxidative superoxide (ROS). Thus it can prevent skin damage caused by ultraviolet (UV)-B radiation.

Aim: The research aims to prove the effectivity of distribution of purple cabbage ethanol cream extract prevented the decrease of dermal collagens on Wistar rats (Rattus norvegicus) exposed to UV-B rays.

Method: This research was arranged with the randomize post-test only control group design. 30 rats were divided into 6 groups containing 5 rats each, there are control group (P1) without distribution of any cream, Treatment Group (P2) with a distribution of base cream (placebo), (P3) sunblock 33 SPF, (P4) 5\%, (P5) $10 \%$, and (P6) $20 \%$ smeared by purple cabbage ethanol cream extract. All groups exposed to UV-B with a total dose of $840 \mathrm{~mJ} / \mathrm{cm}^{2}$ for 4 weeks. Then a sampling rats skin was done for examining the level of collagen skin with Sirius red staining. The level of collagen was calculated by the percentage of the area of the pixel of collagen and was compared with the pixels of entire dermal tissues.

Result: The result demonstrated that the mean of collagens in The First Group/P1 (57.74\%) and P2 (60.84\%) decreased more significantly than P3 (82.17\%), P4 (68.23\%), P5 (76.93\%), and P6 (84.54\%) following UV-B exposure. The Post Hoc result showed that there was no significant difference in the level of collagen in the control group and placebo group and the sunblock group with the purple cabbage's ethanol cream extract group of $20 \%$ ( $p>0.05)$.

Conclusion: the distribution of purple cabbage ethanol cream extract prevented the decrease of dermal collagens on male Wistar rats skin exposed to UV-B.

Keywords: Anthocyanin, antioxidant, purple cabbage ethanol cream extract, dermal collagen, UV-B ray.

Cite This Article: Apsari, K.J.T., Ratnayanti, I.G.A.D., Arijana, I.G.K.N., Sugiritama, I.W. 2020. Topical application of purple cabbage (Brassica oleracea L. var. capitata f. rubra) ethanol cream extract of dermic collagen on male Wistar rats (Rattus norvegicus) exposed to ultraviolet B. Intisari Sains Medis 11(1): 253-258. D0l: 10.15562/ism.v1111.206

${ }^{1}$ Medical Science Study Program, Medical Faculty, Udayana University

${ }^{2}$ Histology Department, Medical Faculty, Udayana University
*Correspondence to: I Gusti Ayu Dewi Ratnayanti, Histology Department, Medical Faculty, Udayana University ratnayanti@unud.ac.id

Received: 2018-04-06 Accepted: 2018-06-16 Published: 2020-03-26

\section{INTRODUCTION}

Indonesia is a tropical country which has a high temperature. ${ }^{1}$ Living in a tropical country means more exposure to sunlight. Sunlight plays an essential role in human health, especially for bone development., ${ }^{2,3}$ However, the exposure also has a negative impact on skin health. Chronic exposure to ultraviolet rays can cause damage to the structure and function of the skin thus accelerating the aging process of the skin; it is called Photoaging. ${ }^{4,5,6}$ Ultra Violet (UV) radiation is divided into three types: UV-A, UV-B, UV-C. ${ }^{7}$ UV-A and UV-B play a role in photoaging while UV-C is absorbed directly by the ozone layer in the atmosphere. ${ }^{7,8}$ In the skin that undergoes photoaging, it can show clinical features of the rough surface, nodule, smooth and rough wrinkles, yellowish, dry and telangiectasia. ${ }^{9,10}$

The pathobiological effects of ultraviolet light (UV-A and UV-B) produce free radicals and cause DNA damage (Deoxyribonucleic Acid) as the source of formation of ROS (Reactive Oxygen Species). ${ }^{6,11}$
Increased of ROS as a result of free radicals because UV-B rays can cause increased lipid peroxidation. ${ }^{12}$ This ROS compound also plays a role in collagen metabolism, because it can destroy the collagen Matrix Metalloproteinase (MMPs), resulting in skin collagen decreased. ${ }^{13,14}$ Its decrement is caused by UV rays and is chained by two most responsible mechanisms AP-1 induction and lower regulation of type II TGF- $\beta$ (Tumor Growth Factor Beta). ${ }^{13,15,16,17}$

Antioxidants are factors that can reduce ROS, both topical and systemic. ${ }^{18}$ Based on the source of the acquisition there are two kinds of antioxidants, namely natural antioxidants and synthetic antioxidants (synthetic). ${ }^{19}$ The human body does not have antioxidant reserves in excess level, so if there is exposure to excessive radicals, then the body needs exogenous antioxidants. ${ }^{20}$ The presence of concerns about the possible unknown side effects of synthetic antioxidants causes natural antioxidants to be a much-needed alternative. ${ }^{20,21}$ 
Indonesia is one of the countries with largest natural wealth in the world. ${ }^{22}$ There are nutritious plants as a source of abundant natural antioxidants, one type of plant that can be utilized is the Purple Cabbage found in Luwus Village, Baturiti, Tabanan, Bali. ${ }^{23}$ Based on research conducted by Neelufar, anthocyanin on purple cabbage was found to have antioxidant power 150 times stronger than flavonoids. ${ }^{24}$ According to a study conducted by Kim and Wampler, the anthocyanin content of purple cabbage is $355 \mathrm{mg} / 100 \mathrm{~g}$ which is higher when compared to concentrated sweet potatoes $(61.85 \mathrm{mg} / 100 \mathrm{~g})$ and purple corn extract containing anthocyanin as much as $210.40 \mathrm{mg} / 100 \mathrm{~g} .{ }^{25,26,27} \mathrm{The}$ anthocyanins contained in purple cabbage (Brassica oleracea L. var, capitata f. Rubra) are (cyanidin-3-diglucoside-5-glucoside). ${ }^{28}$ Antosianin protects collagen through a mechanism of inhibition of phosphorylation of tyrosine kinase, the enzyme inactivation of EGF (Epidermal Growth Factor). ${ }^{29,30}$

\section{METHODS}

\section{Subject}

Based on the calculation using Federer's formula, the subject of the study used 30 rats of Wistar strain (Rattus norvegicus), male, 3-4 months old, weighing 150-200 grams, divided into six groups, each with five rats. The subject did not appear to be active or sick or die including exclusion criteria. ${ }^{31}$

\section{Design of experiment}

This research design used the randomized post test only control group design.

\section{Subject Treatment}

Subjects were divided into 6 (six) groups with each leveling to 5 rats. The control group exposed only UV-B rays (P1), Placebo Group (P2), Group Sunblock cream SPF 33 (P3), Group cream extract ethanol of purple cabbage 5\% (P4), Group extract ethanol of purple cabbage 10\% (P5), and Group cream extract ethanol of purple cabbage 20\% (P6). UV-B light from Polish Ultraviolet broadband, Philips type UVB-311nm (pl-s 9w/01) lamp. Rats from all treatment groups were given UVB exposure three times a week for 4 weeks beginning with a dose of $50 \mathrm{~mJ} / \mathrm{cm} 2$ for 50 seconds in the first week, followed by $70 \mathrm{~mJ} / \mathrm{cm} 2$ for $70 \mathrm{~s}$ in the second week and 2 weeks later with $80 \mathrm{~mJ} / \mathrm{cm} 2$ for 80 seconds, so the total UVB received is $840 \mathrm{~mJ} / \mathrm{cm} 2$ for 4 weeks. The rats were left first for 24 hours after irradiation tended to exclude the effects of acute effects. ${ }^{32}$

$$
\text { Level of collagen }=\frac{\text { pixel of collagen area }}{\text { pixels of entire dermal tissues }} \times 100 \%
$$

\section{Application of substances}

All rats were shaved on their backs before being applied with the cream by their respective treatment groups. Each cream according to treatment was administered as much as $0.05 \mathrm{mg} / \mathrm{cm} 2$, applied two times daily about 20 minutes before irradiation (to give a topical absorption time into the skin) and 4 hours after irradiation (ROS formation started 4 hours after exposure). Topical application of the material remains on a day without irradiation. ${ }^{32}$

\section{Histopathological Observation}

The rats were euthanasia first with anesthesia by inserting into a jar containing ether-cotton. ${ }^{33}$ Subsequent samples were taken from the back tissue of Wistar rats with $2 \mathrm{~mm}$ deep subcutaneous, $2 \mathrm{~cm}$ long and $2 \mathrm{~cm}$ wide using scalpel no.10 and anatomical scissors. Samples were then prepared for histopathologic examination with preparations using Sirius red staining. Collagen texture was shown in bright red on the picture of the preparations taken using the Optilab Pro camera (Miconos, Indonesia) and the Olympus $\mathrm{Cx} 41$ microscope with an objective magnification 400 times. The result of preparing photos is stored in JPEG format, then calculated by using Adobe Photoshop CS3 and Image J software.

\section{Statistic Analysis}

Data were processed using IBM SPSS 21.0. The analysis begins with a descriptive test to look at the characteristics of the data, test the normality of data using Shapiro-Wilk, homogeneity test using Levene's test. Comparative analysis between groups using One Way ANOVA. Post-Hoc analysis was performed after it was found that there were significant differences between the treatment group and normal, homogeneously distributed data then PostHoc test with LSD (Least Significant Differencetest) test. There was a significant difference in the group if $(\mathrm{p}<0.05)$.

\section{RESULTS}

Treatment effect analysis was tested based on a percentage of collagen between groups after treatment. The result of significance analysis with One Way ANOVA test was shown in Table 1. The test showed that the value of $\mathrm{F}=43.28$ and $\mathrm{p}$-value $=0.000$. This means that there was a difference in the collagen in the six groups $(p<0.05)$. A further test with the post-hoc test was Least Significant Difference-test (LSD). The test results were presented in Table 2.

The above test results showed that there was no significant difference in the level of collagen in the control group and placebo group and the sunblock 
Table 1 One Way ANOVA Analysis Result Collagen Dermis Male Wistar Rats Exposed to Ultraviolet B Rays in Each Group

\begin{tabular}{llllll}
\hline Subject group & N & Mean & SB & $\boldsymbol{F}$ & $\boldsymbol{P}$ \\
\hline Control & 5 & $57.74 \%$ & 3.67 & 43.28 & 0.000 \\
Placebo & 5 & $60.84 \%$ & 5.78 & & \\
Sunblock & 5 & $82.17 \%$ & 3.44 & & \\
$5 \%$ & 5 & $68.23 \%$ & 2.95 & \\
$10 \%$ & 5 & $76.93 \%$ & 2.21 & \\
$20 \%$ & 5 & $84.54 \%$ & 3.83 & \\
\hline
\end{tabular}

$\mathrm{n}=$ number of sample,

$\mathrm{SB}=$ Standard Deviation

$\mathrm{F}=$ Levene's test,

$\mathrm{P}=$ Significancy

Table 2 Results of Post-Hoc LSD Analysis Number of Collagen Dermis Male Wistar Rats Exposed to Ultraviolet B rays in Each Group

\begin{tabular}{ccccc}
\hline & & \multicolumn{2}{c}{ Cl 95\% } & \multirow{2}{*}{ P } \\
\cline { 2 - 3 } Groups & Mean Diff. & Lower bound & Upper bound & 0.210 \\
Kontrol vs Plasebo & -3.1 & -8.07 & 1.87 & $0.000^{*}$ \\
Kontrol vs Sunblok & -24.43 & -29.4 & -19.46 & $0.000^{*}$ \\
Kontrol vs 5\% & -10.49 & -15.46 & -5.52 & $0.000^{*}$ \\
Kontrol vs 10\% & -19.19 & -24.15 & -14.22 & $0.000^{*}$ \\
Kontrol vs 20\% & -26.8 & -31.77 & -21.84 & $0.000^{*}$ \\
Plasebo vs Sunblok & -21.32 & -26.1 & -16.36 & $0.005^{*}$ \\
Plasebo vs 5\% & -7.39 & -12.4 & -2.42 & $0.000^{*}$ \\
Plasebo vs 10\% & -16.08 & -21.05 & -11.12 & $0.000^{*}$ \\
Plasebo vs 20\% & -23.7 & -28.67 & -18.73 & $0.000^{*}$ \\
Sunblok vs 5\% & 13.94 & 8.97 & 18.9 & $0.040^{*}$ \\
Sunblok vs 10\% & 5.24 & 0.27 & 10.2 & 0.333 \\
Sunblok vs 20\% & -2.38 & -7.34 & 2.59 & $0.001^{*}$ \\
5\% vs 10\% & -8.7 & -13.67 & -3.73 & $0.000^{*}$ \\
$5 \%$ vs 20\% & -16.31 & -21.28 & -11.345 & $0.004^{*}$ \\
10\% vs 20\% & 7.62 & 2.65 & 12.58 &
\end{tabular}

* $=$ Significantly different at $\mathrm{p}<0.05$

group with the cream extract ethanol extract group of $20 \%$.

\section{Histological Appearance}

The histological preparation of Wistar rats' skin with Sirius red staining appears as shown on the Figures 1.

\section{DISCUSSION}

\section{Characteristics of the Sample}

This study used Wistar rats (Rattus norvegicus) as experimental animals because they have the equation of organ structure with humans, other than that the short and not thick fur owned by Wistar rats facilitate research using skin texture as research samples. ${ }^{34}$ The sexes selected were male rats not affected by the estrous cycle (reproductive cycle) and pregnancy (hormonal). ${ }^{34}$ Selected age ranges from 3-4 months because at this age rats have similarities with adult human age and have not experienced intrinsic aging, so the collagen reduction results in this study purely a result of UV-B not from the aging process. ${ }^{33,35}$

\section{Collagen On Male Wistar Rats}

In this study showed that in the control and placebo groups after the post-hoc test, $p>0.05$ was obtained, which means there is no difference in the level of collagen (Table 2). So the effect of prevention of the reduction of the level of pure collagen is due to the giving of purple cabbage ethanol extract and decreasing the level of collagen in all treatment groups resulting from UV-B. In the Control and 

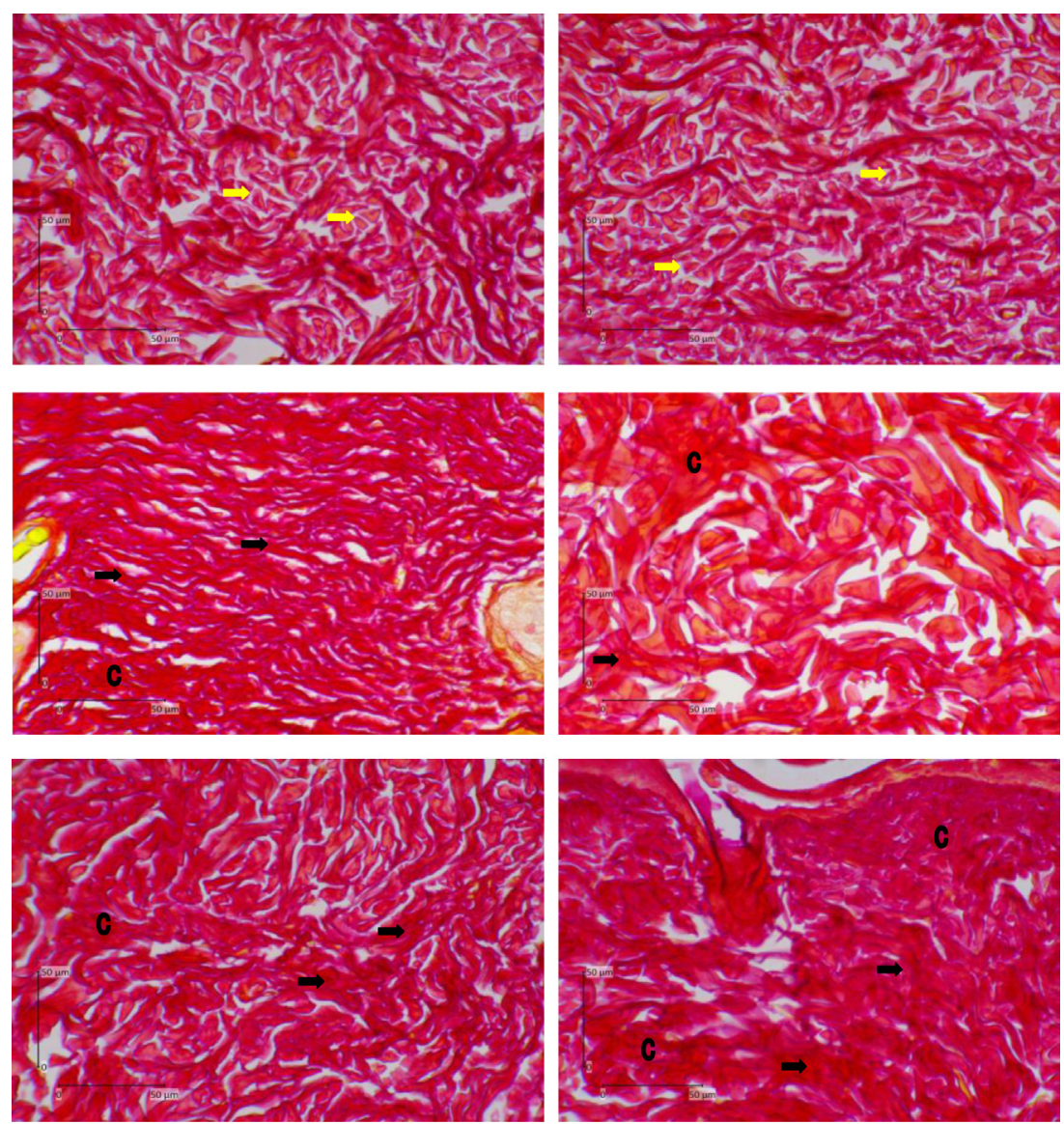

Figure 1 Male wistar rats collagen with Sirius red staining (400x Magnification). Note: upper left $=$ Control $(\mathrm{P} 1)$; upper right $=$ Placebo (P2); middle left $=$ Sunblock (P3); middle right $=5 \%(\mathrm{P} 4)$; lower left $=10 \%(\mathrm{P} 5)$; lower right $=20 \%(\mathrm{P} 6) ; \mathrm{C}=$ Collagen .

Placebo Groups showed damage to the composition and structure of collagen tissue, so the collagen fibers were not intact (fragmented) and did not absorb the red staining of Sirius red well (Figures 1).

The decrease in the level of collagen dermis caused by ultraviolet rays which can form free radicals that can activate mitogen-activated protein kinase pathways (MAPK) as collagenase producer (MMP-1) that can destroy collagen. The oxygen molecule $(\mathrm{O} 2)$ present at the bottom of the epidermis is the main target of UV-B rays that enter the skin. UV rays that penetrate the skin can as a donator of an electron in an oxygen molecule that causes oxygen to become unstable, then become aggressive free radicals. In the dermal layer, ultraviolet $B$ radiation causes collagen damage at a higher rate than naturally caused aging damage. ${ }^{6,9,10,11}$

Sunlight damages collagen fibers and causes abnormal accumulation or elastin accumulation. When this elastin accumulates, an enzyme called metalloproteinase will be produced in large quantities. ${ }^{10,11}$ Usually, this enzyme works to repair skin damaged by light by producing and forming collagen, but this process does not always work well, and some of these proteins actually destroy collagen, the result is the emergence of a collection of irregular collagen fibers known as solar scars., ${ }^{5,11}$ When the skin keep this imperfect repair process repeatedly, it would forms wrinkles. ${ }^{9,10}$ In photoaging skin, collagen fibers are disorganized. ${ }^{5,6}$ The results of this study are in accordance with the results of Gilchrest and Krutmann'sresearch, which found that the skin that experienced photoaging decreased the number of precursor collagen type I and III. ${ }^{36}$ Similarly, the Moertolo study showed that UV-B exposure with a total dose of $840 \mathrm{~mJ} / \mathrm{cm} 2$ for 4 weeks may result in a decrease in the level of collagen in the skin of Wistar rats (Rattus norvegicus). ${ }^{37}$ It is known that UV-B causes more DNA cell damage. Damage that can be caused in the form of DNA lesions in cyclobutane pyrimidine dimer. Clinically the disorder is erythema or redness. The end result of glycation or advanced glycation end product (AGE) that accumulates in long-lived proteins such as extracellular matrix also turns out the function as a sensitizer for ultraviolet, which can damage dermal fibroblasts cells. Ultraviolet light is also shown to increase collagen degradation through activation of MMPs Ultraviolet rays can stimulate the synthesis of MMP-1 and MMP-3 through the release of TNF- $\alpha$ (Tumor Necrosis Factor Alpha) by keratinocytes and fibroblasts. UV-B directly affects DNA damage mainly in two large lesions of cyclobutane dimer and pyrimidine-pyrimidone photo product, which directly affects nucleic acid synthesis. Although nuclear DNA can repair itself, DNA damage is rarely improved entirely and has the potential to become malignant cells. ${ }^{38}$

In this study also showed that in the Treatment Group given 5\%, $10 \%$ and $20 \%$ of purple cabbage ethanol extract can prevent the decrease in the level of dermal collagen caused by UV-B exposure (Figures 1). In this study also showed that in the Treatment Group given 5\%, 10\% and 20\% of purple cabbage ethanol extract can prevent the decrease in the level of dermal collagen caused by UV-B exposure. ${ }^{39}$ A study by Moertolo showed that the presence of phenol compounds, one of the class of flavonoid (anthocyanin class of cyanidin-3-glucoside and peonidin-3-glucoside) in black rice which has antioxidant activity in preventing the decrease of collagen group treatment more quickly than control group. ${ }^{37}$ Similar research has also been conducted by Dianasari about giving cream of purple corn extract and Widiyowati research about green tea extract cream giving that anthocyanin content as an antioxidant can preventing collagen reduction in the faster treatment group than the control group. ${ }^{27,40}$

Several previous studies have shown that polyphenolic compounds contained in purple cabbage 
have essential effects on the body, such as protection against cardiovascular disease, diabetes mellitus, anti-inflammation, anticancer, and antioxidants. ${ }^{41}$ In accordance with some studies both in animals and humans that prove that polyphenol compounds can prevent the formation of free radicals and lipid peroxidation due to exposure to ultraviolet light. The mechanism of action of polyphenols in inhibiting damage caused by UV rays encompasses three effects, namely sunscreen effects, anti-inflammatory effects, and antioxidants. Most of the natural polyphenols are pigments, generally yellow, red or purple and absorb UV radiation. When administered topically, polyphenols will prevent the entry of radiation into the skin layer. Radiation that can be absorbed by polyphenols includes the entire UV-B spectrum and some UV-A and UV-C. Through the ability of this absorption natural polyphenols can act as a sunscreen..$^{37}$ The strength of polyphenols to work as sunscreens can reduce inflammation, oxidative stress and DNA damage caused by UV radiation in the skin. In topical administration, the photoprotective ability of polyphenols is obtained through the sunscreen effect. ${ }^{42,43}$

In this research, the level of collagen between the sunblock group and the group of ethanol extract of purple cabbage $20 \%$ after the post-hoc test was obtained $p>0.05$ (Tabel 2), which means no significant difference. This suggests that the effect is more vital to prevent a decrease in the level of collagen compared to the group given 5\%, $10 \%$ cream, placebo and control groups which means the addition of cream doses can add cream effectiveness as strong as sunblock as a prototype antioxidant that can provide protection from UV-B exposure. According to Irsyadah's research, the use of sunblock on some SPF (Sun Protection Factor) values can provide the protection from UV-B exposure. ${ }^{44}$ Application of cream extract of purple cabbage ethanol can be used to protect the skin from the effects of UV radiation that can cause both erythemas in acute effects and chronic effects that can cause premature skin aging (photoaging).

The purple cabbage (Brassica oleracea L. var, capitata $\mathrm{f}$. Rubra) also contains vitamin $\mathrm{C}$, which is an antioxidant that serves to keep the cells, including skin cells. ${ }^{28,45}$ In addition, vitamin $\mathrm{C}$ also plays an active role in the production of collagen. Vitamin C works as a collagen protector of the skin by donating two electrons derived from the double bond between the second and third carbon so that ROS is not formed. In this process, vitamin $\mathrm{C}$ will oxidize to produce dehydroascorbic acid, which can then be reduced back to ascorbic acid with the help of the enzyme 4-hydroxyphenylpyruvate dioxygenase. ${ }^{46}$ In collagen biosynthesis, vitamin $\mathrm{C}$ has a role as a cofactor of prolyl hydroxylase enzyme and lysyl hydroxylase. In collagen found many prolines and lysine, hydroxylation both will stimulate the formation of new collagen. ${ }^{47,48}$ Similar research results by Soejanto, vitamin C content found in red pomegranate extract cream can prevent the decrease in the level of collagen. ${ }^{49}$

\section{CONCLUSION}

Based on the result of this research, it can be concluded that $5 \%, 10 \%$ and $20 \%$ of the purple cabbage (Brassica oleracea L. var, capitata f. Rubra) ethanol cream extract can prevent the decrease of dermal collagen of male Wistar (Rattus norvegicus) dermis exposed to UV-B.

\section{REFERENCES}

1. Wardiyatmoko. 2006. Geografi. Jakarta: Erlangga.

2. Holick MF. Sunlight and vitamin D for bone health and prevention of autoimmune disease, cancer and cardiovascular disease. American Journal of Clinical Nutrition. 2004; 80:1678-88.

3. Langsetmo L, et al. Calcium and Vitamin D Intake and Mortality: Results from the Canadian Multicentre Osteoporosis Study (CaMos). The Journal of Clinical Endocrinology and Metabolism. 2013;98.

4. Masnec IS and Situm M. Skin Aging. Acta Clin Croat. 2010;49:515-519.

5. Varani J, Quan TH and Fisher GJ. Mechanism and Pathophysiology of Photoaging and Chronological Skin Aging. In: Rhein, L.D., Fluhr J.M., editors. Aging Skin: Current and Future Therapeutic Strategies 1st ed.USA: Allu Red Bussiness Media; 2010:1-25.

6. Frenske NA and Lober CW. Aging and its Effect on the skin. In: Dermatology. 3rd ed. Philadelphia: W.B Saunders Company; 2012:107-122.

7. Environmental Protection Agency. EPA: UV Radiation; 2010. [Online]. Available from: https://www.epa.gov/sites/ production/files/documents/uvradiation.pdf. Accessed January 20, 2018.

8. Arakane K and Naru E. 2016. Cosmeceuticals and Active Cosmetics, 3rd Ed., 281. New York: CRC Press.

9. Glogau RGS.Photo Aging and Aging Skin. In: Rigel D.S., Weiss R.A., Linn H.W., Dover J.S. editors. Photoaging, 2nd ed. Canada: Maarced Decker Inc. 2004:65-73.

10. Moyal D and Fountainer A. Acute and Chronic Effects of Ultraviolet. What are they and How to Study. In: Rigel, D.S., Weiss R, A., Linn H.W., Dover J.S. editor.Photoaging 2nd ed. Canada: Marceed Decker Inc.2004:15-54.

11. Garmyn M, Vander Oord J, Cho S, and Kang S. Clinic and Histological change in Photoaging. In: Rigel, D.S., Weiss, R. A., Linn, H.W., Dover, J. S. editors. Photoaging, 2nd ed. Canada: Maarced Decker Inc. 2004:33-55.

12. Cunningham WBR and Maibah H. Aging and Photoaging. In: Textbook of Cosmetic Dermatology. 3 rd ed. London: Francis Taylor. 2005:443

13. Rabe JH, Mamelak AJ, Mc Elgunn PJS, and Morison WL. Photoaging Mechanism and Repair. J.Am.Acad of Dermatol. 2006;55: 1-19.

14. Quan T, Qin Z, Xia W, Shao Y, Voorhees JJ and Fisher G. Matrix- Degrading Metalloproteinases in Photoaging. Journal of Investigative Dermatology Symposium Proceedings. 2009; 14: 20-24.

15. Rigel DS, Weis RA, Lim HW, and Dover JS. Photoaging. New York: Marcel Dekker, Inc.S.I., Gilchrest, B.A., Paller, A.S., Leffel, D.J., editors. Fitzpatrick's Dermatology in General Medicine. 6th. ed. New York: McGraw-Hill. 2004:517-41. 
16. Gancevicien R, Liakou AL and et al. Skin Anti-aging Strategies. Dermatoendocrinol. 2012; 4(3): 308-319.

17. Rhein LD and Santiago JM. Aging Skin: Current and future therapeutic Strategies 1st ed.USA: AlluRed Bussiness Media; 2010:26-81.

18. Ardhie AM. Radikal Bebas dan Peran Antioksidan dalam Mencegah Penuaan. Medicinus. 2011; 24(1): 4-9.

19. Masaki H. Role of antioxidant in the Skin: Anti Aging effects. J Dermatol Science. 2010; 58:85-90.

20. Afaq F and Mukhtar H. Antioxidants for The Prevention of Photoaging. In: Rhein, L.D., Fluhr J.M., editors. Aging Skin: Current and Future Therapeutic Strategies 1st ed.USA: Allu Red Bussiness Media; 2010:273-93.

21. Chen L, Hu JY, and Wang SQ. The Role Antioxidant in Photoprotection: a critical review. J.Am.Acad. Dermatol July, 496907; 2012. [Online] Available from http://www. ciencedirect.com/science/article/pii/SO1909622120013. Accessed 20 January 2017.

22. Heyne K. Tumbuhan Berguna Indonesia. Jakarta: Badan Litbang Kehutanan; 1987:831-833.

23. Dalimartha S. Atlas Tumbuhan Obat Indonesia. Jilid Kedua. Jakarta: Trubus Agriwidya; 2000:116 - 119.

24. Neelufar S, Alekhya T, and Sudhakar K. Pharmacognostical and phytochemical formulation evaluation of Brassica Oleracea Linn Var. Capitata f. Rubra (The Red Cabbage). Journal of Pharmaceutical Biology. 2012; 2: 43-46.

25. Kim Y and Wampler DJ. Anthocyanin Content in Various Anthocyanin Rich Fruits and Vegetables. SENSUS; 2009.

26. Husna NE, Novita M, dan Rohaya S. Anthocyanins Content and Antioxidant Activity of Fresh Purple Fleshed Sweet Potato and Selected Products. AGRITECH; 2013;33(33).

27. Dianasari R. Pemberian Krim Ekstrak Jagung Ungu (Zea Mays) Menghambat Peningkatan Kadar MMP-1 dan Penurunan Jumlah Kolagen pada Tikus Wistar (Rattus norvegicus) yang Dipapar Sinar UV-B. (Thesis). Denpasar : Universitas Udayana; 2014.

28. Shama SN, Alekhya T, and Sudhakar K. Pharmacognostical \& Phytochemical Evaluation of Brassica oleracea Linn var. capitata f.rubra (The Red Cabbage). Journal of Pharmaceutical Biology. 2012; 2(2):43-46.

29. Rokayya S, Chun-Juan L, Yan Z, Ying L, and Chang-Hao S. Cabbage (Brassica oleracea L. var. capitata) Phytochemicals with Antioxidant and Anti-inflammatory Potential. Asian Pac J Cancer Prev. 2013; 14 (11): 6657-62.

30. Bei R, Masuelli L, Turriziani M, Volti GL, Malaguarnera M, and Galvano F. Impaired Expression and Function of Signaling Pathway Enzymes by Anthocyanins: Role on Cancer Prevention and Progression. Journal of Enzyme Inhibition and Medical Chemistry. 2009; 5:184-97.

31. Federer WT. Experimental Design. Theory and Application. Oxford and IBG Publishing Co. New Delhi, India; 2008.

32. Vani TA. Pemberian krim Ekstrak Umbi Ubi Jalar Ungu (Ipomea batatas L) Mencegah Penurunan Jumlah Kolagen Kulit Tikus Putih Galur Wistar (Rattus norvegicus) Yang Dipapar Sinar Ultraviolet B. (Thesis). Denpasar : Universitas Udayana; 2013.

33. Santoso MIE. Buku Ajar Etik Penelitian Kesehatan. Penerbit Universitas Brawijaya Press (UB Press). Malang; 2011.

34. Guillen J. FELASA guidelines and recommendations. J Am Assoc Lab Anim Sci. 2012; 51(3):311-321.
35. Smith JB and Mangkoewidjojo S. 1988. Pemeliharaan, Pembiakan dan Penggunaan Hewan Percobaan di Daerah Tropis. Jakarta: Penerbit Universitas Indonesia.

36. Gilchrest BA and Krutmann J.Skin Aging.Springer Publisher; 2006.

37. Moertolo YN. Pemberian Krim Ekstrak Beras Hitam (Oryza sativa L. indica) Menghambat Penurunan Jumlah Kolagen Pada Tikus (Rattus norvegicus) Galur Wistar Yang Dipapar Sinar Ultra Violet-B. Thesis. Denpasar: Universitas Udayana; 2015.

38. Gilchrest BA and Yaar M. Aging of Skin. In: Fitzpatrick T.B. et al., editors. Dermatology in General Medicine, Mc Graw-Hill Book Co 2; 2000:1386-87.

39. Hong $\mathrm{Z}$ and Meng $\mathrm{Z}$. Microencapsulation of anthocyanins from red cabbage. Int Food Res Jl. 2015; 22: 2327-32.

40. Widiyowati $\mathrm{H}$, et al. Pemberian Krim Ekstrak Teh Hijau (Camellia sinensis) Dapat Mencegah Penurunan Jumlah Kolagen Dermis dan Peningkatan Kadar Matriks Metalloproteinase-1 pada Mencit Balb -C Yang Dipapar Sinar Ultraviolet B. E-Jurnal Indonesian Journal of Anti Aging Medicine. 2017;1(1):10-16.

41. Jaiswal AK, Rajauria G, and et al. Phenolic Composition, Antioxidant Capacity and Antibacterial Activity of Selected Irish Brassica Vegetables. Natural Product Communications. 2011;6(0).

42. Pandel R, Poljsak B, Godic A, and Dahmane R. Skin Photoaging and The Role of Antioxidants in Its Prevention. International Scholarly Research Notices. ISRN Dermatology; 2013.

43. Nichols JA and Katiyar SK. Archives of Dermatology Research. 2010;302:71-83.

44. Irsyadah FT, Astono TH, Martosudiro M, and Bedjo. Efektivitas Penggunaan Sunblock Komersial Pada Beberapa Nilai Spf (Sun Protection Factor) Sebagai Pelindung Spodoptera Litura Nuclear Polyhedroses Virus (Slnpv) Dari Sinar Ultraviolet. Jurnal HPT. 2014;2(1):2338 - 4336.

45. Tahria Z, Riffat $F$ and et al. In Vitro Assessment of Antibacterial Activity of Methanol Extract of Brassica Oleracea against Selected Bacterias. JLUMHS. 2013;12(3).

46. Telang PS. Vitamin C in Dermatology; 2013. [Online]. Available from: http://www.ncbi.nlm.gov/pmc/articles/ PMC3673383. Accessed January 20, 2018.

47. Zussman J, and Ahdout J. The Role of Vitamins in Skin Care Products; 2010.

48. Wardana, I.N.G., Widianti, I.G.A., Wirata, G. 2018. Testosterone increases corpus cavernous smooth muscle cells in oxidative stress-induced rodents (Sprague-Dawley). Bali Medical Journal 7(2): 313-322. DOI: 10.15562/bmj. v7i2.970

49. Soejanto, AS. Pemberian Krim Ekstrak Metanolik Buah Delima Merah (Punica granatum) Menghambat Penurunan Jumlah Kolagen Dermis Kulit Mencit (Mus gusculus) Yang Dipapar Sinar Ultraviolet B. E-Jurnal Indonesian Journal of Anti Aging Medicine. 2017;1(1):1-9.

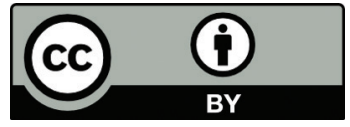

This work is licensed under a Creative Commons Attribution 